\title{
Defoliation and cold-hardiness of northern wheatgrass
}

\author{
BRENDAN L. KOWALENKO AND J.T. ROMO
}

Authors are former graduate student and professor, Dept. of Crop Sci. and Plant Ecology, 51 Campus Drive, Univ. of Saskatchewan, Saskatoon, Sask. S7N SA8. JTR is corresponding author.

\begin{abstract}
Freezing temperatures in winter were hypothesized to be a major cause of mortality of tillers following defoliation of northern wheatgrass (Agropyron dasystachyum [Hook.] Scribn., syn. Elymus lanceolatus [Scribn. \& Smith] Gould). Cold-hardiness of northern wheatgrass tillers was determined following a single mowing to a 5-cm stubble height in late May, June, July, or August in 1992 or 1993 in southwestern Saskatchewan. An unmowed control was also included. Cold-hardiness was determined in early and late winter immediately following mowing by: 1) exposing tillers to controlled temperatures ranging from $\mathbf{- 3}$ to $-36^{\circ} \mathrm{C}$, or; 2) exposing them to $-15^{\circ} \mathrm{C}$ for 0 to 15 days. The $\mathrm{LT}_{50}$ (temperature at which $50 \%$ of tillers died) of northern wheatgrass tillers in early winter ranged from -29.5 to $<-36.0^{\circ} \mathrm{C}$ in 1992-93, and averaged $-24.0^{\circ} \mathrm{C}$ in 1993-94. In late winter $L_{50}$ ranged from -18.1 to $-22.6^{\circ} \mathrm{C}$ in $1992-1993$, and it averaged $-22.0^{\circ} \mathrm{C}$ in 1993-1994. The LDur 50 (duration at which $50 \%$ of tillers died) of tillers exposed to $-15^{\circ} \mathrm{C}$ for 0 to 15 days ranged from 8.0 to 13.1 days in early winter, and 2.7 to 4.7 days in late winter. Unexpectedly mowed tillers were generally more cold-hardy than those from control. In early winter $\mathrm{LT}_{50}$ was 1.5 to $10^{\circ} \mathrm{C}$ lower for mowed than control tillers. The hypothesis that defoliation reduces cold-hardiness of northern wheatgrass was rejected. The degree or duration of cold stress in the field is generally insufficient to reduce tiller survival in northern wheatgrass. Late winter through early spring is a critical period for tiller survival of northern wheatgrass because cold-hardiness declines this time of the year. Maintaining insulating cover can moderate soil temperatures and reduce damage to plants from freezing temperatures.
\end{abstract}

Keywords: Agropyron dasystachyum (Hook.) Scribn., cold stress, crown temperatures, Elymus lanceolatus (Scribn. \& Smith) Gould, freezing tolerance, grazing, Northern Mixed Prairie, tiller survival

Freezing temperatures during winter, and the attendant cold stress that plants experience, may substantially impact plants on the Canadian Prairies. Plants must develop cold-hardiness in autumn, and maintain it throughout winter and early spring (Burke et al. 1976). Defoliation can directly or indirectly alter

This research was funded by the Saskatchewan Agriculture-Agriculture Development Fund and the Natural Sciences and Engineering Research Council.Thanks are extended to Dr. M.R. Haferkanp for constructive comments on an earlier version of this paper.

Manuscript accepted 3 Feb. 1997. cold-hardiness and survival of plants. Improper timing, frequency, or intensity of defoliation can reduce winter survival of tillers (Lawrence and Ashford 1969a, 1969b, Harrison and Romo 1994). Removal of insulating, vegetative cover through grazing also creates a colder winter environment for plants, increasing cold stress (Johnston et al. 1971).

Northern wheatgrass (Agropyron dasystachyum [Hook.] Scribn., syn. Elymus lanceolatus [Scribn. \& Smith] Gould), a perennial, cool season, rhizomatous species is a dominant on soils of heavy texture in southern Saskatchewan and Alberta (Coupland 1950). Slow recovery of aboveground net primary production following defoliation of northern wheatgrass (Kowalenko and Romo 1997) may reflect increased sensitivity of plants to freezing temperatures and a colder microenvironment. Effects of defoliation on cold-hardiness of northern wheatgrass have, however, not been evaluated. Our hypothesis was that increased mortality of tillers and reduced production of northern wheatgrass are consequences of grazing on rangelands dominated by this perennial. We predicted that defoliation during the growing season would reduce cold-hardiness of northern wheatgrass. The objective of this study was to examine the effects of 4 different dates of mowing during the growing season on cold-hardiness of northern wheatgrass the following winter.

\section{Materials and Methods}

\section{Site Description}

Research was conducted from 1992 through 1994 at the University of Saskatchewan, Matador Research Station, about 70 $\mathrm{km}$ north of Swift Current, Saskatchewan $\left(50^{\circ} 42^{\prime} \mathrm{N}, 107^{\circ} 43^{\prime} \mathrm{W}\right.$, elevation $685 \mathrm{~m}$ ). Soils are heavy clay belonging to the Rego Brown and Calcareous Brown subgroups in the Sceptre association of the Chernozemic Order (Aridic Borolls) (Coupland et al. 1974). Temperatures of the region average $3.3^{\circ} \mathrm{C}$, and range from a monthly mean of $-14.5^{\circ} \mathrm{C}$ in January to $18.8^{\circ} \mathrm{C}$ in July (Environment Canada 1992). Average daily air temperature is typically $<0^{\circ} \mathrm{C}$ from late October or early November until early to mid-March. Minimum recorded temperatures are $-19.4,-30.6$, $-39.4,-42.8,-38.9,-35.6$, and $-26.7^{\circ} \mathrm{C}$ for October, November, December, January, February, March, and April, respectively. Annual precipitation averages $327 \mathrm{~mm}$ with about $60 \%$ received from May through August.

Vegetation of this clayey range site belongs to the AgropyronKoeleria faciation of the Northern Mixed Prairie with northern and western wheatgrass (Agropyron smithii Rybd., syn. Pascopyrum smithii [Rydb.] Löve) potentially producing about 75\% of the phytomass (Coupland et al. 1974). Typically $80-85 \%$ 
of this total is produced by northern wheatgrass (Coupland 1950). This range, ungrazed for over 25 years, is in excellent condition.

Precipitation records were obtained from Beechy, Saskatchewan, $40 \mathrm{~km}$ northeast of the study site. Annual precipitation in 1992 was $110 \%$ of the 30-year mean of $327 \mathrm{~mm}$, whereas precipitation in 1993 was $123 \%$ of normal.

\section{Experimental Design}

Five treatments of defoliation (mowing) to a $5-\mathrm{cm}$ stubble in late May, late June, late July, or late August, plus an unmowed control, were imposed in 1992 and 1993. Plants were mowed only once and mowed material was removed from the plots. Treatments were applied in a randomized-complete-block design with 5 replicates in 1992 and 4 replicates in 1993. Plots established in 1992 were $5 \times 10 \mathrm{~m}$ whereas those in 1993 were $5 \times 5 \mathrm{~m}$.

The first winter following mowing, northern wheatgrass tillers were collected from each replicate, and their cold-hardiness was determined. Early winter tests on 11 November 1992 and 30 October 1993 examined tillers at, or close to, their maximum annual level of cold-hardiness (Gusta and Chen 1987). Late winter tests on 6 March 1993 and 19 March 1994 examined the effects of winter dormancy on the cold-hardiness of tillers. Tillers were collected by removing patches of sod from plots to about a $20-\mathrm{cm}$ depth. Tillers were then separated from soil either in the field or laboratory, and placed in moist "Redi-Earth" potting medium in metal containers, $6.0 \mathrm{~cm}$ in diameter and $4.5 \mathrm{~cm}$ tall.

In Experiment I, conducted in both years, tillers were exposed to 10 freezing temperatures in a randomized-complete-block design using 2 replicates of 20 tillers container ${ }^{-1}$ for each mowing treatment and freezing temperature. Containers with tillers were placed in a programmable freeze chamber and held at $-3^{\circ} \mathrm{C}$ for 12 hours to facilitate uniform freezing. Chamber temperature was reduced $2^{\circ} \mathrm{C}$ hour ${ }^{-1}$ until it reached $-19^{\circ} \mathrm{C}$, then at $5^{\circ} \mathrm{C}_{\text {hour }}^{-1}$ until it reached $-36^{\circ} \mathrm{C}$. Containers with tillers were removed from the freeze chamber at $-3,-6,-12,-18,-21,-24,-27,-30,-33$, and $-36^{\circ} \mathrm{C}$.

In Experiment II, conducted in 1993-94, tillers were exposed to $-15^{\circ} \mathrm{C}$ for 11 durations in a randomized-complete-block design using 4 replicates (containers) of 10 tillers for each mowing and freezing treatment. Temperature of the freezer was held at $-3^{\circ} \mathrm{C}$ for 12 hours and then reduced $2^{\circ} \mathrm{C}$ hour ${ }^{-1}$ until it reached $-15^{\circ} \mathrm{C}$. The $-15^{\circ} \mathrm{C}$ temperature represents the approximate minimum temperature measured at the crown level in the field (Romo, unpub. data). Tillers were then transferred to a freezer that was set at $-15^{\circ} \mathrm{C}$. Temperatures in this freezer increased 5 to $7^{\circ} \mathrm{C}$ during placement of samples and required about 12 hours to stabilize at $-15^{\circ} \mathrm{C}$. In the late winter test in 1994 , the temperature stabilized at about $-16^{\circ} \mathrm{C}$. Containers with tillers were removed after $0,2,12,24$, or 48 hours, and $3,4,5,6$, 7 , or 15 days.

Tillers removed from freezing treatments in 1993 and 1994 were stored at 2 to $5^{\circ} \mathrm{C}$ for 1-3 days to prevent temperature shock. Tillers were then transplanted into flats filled with moist "Redi-Earth" potting mixture, and placed in a greenhouse at $20^{\circ} \mathrm{C}$ with 12 hours of light averaging $180 \mu \mathrm{mol} \mathrm{m} \mathrm{m}^{-2} \mathrm{~s}^{-1}$. After 5 weeks, tiller survival and shoot biomass were determined for each mowing treatment and freezing temperature. Tillers were clipped at soil level, dried at $80^{\circ} \mathrm{C}$ for 48 hours, and weighed.

In 1993-94, water content on a dry-weight basis, was determined on 4 replicates of 10 tillers from each mowing treatment. Tillers were weighed fresh, oven-dried at $80^{\circ} \mathrm{C}$ for at least 24 hours, and reweighed.

\section{Data Analysis}

Effects of freezing on $\mathrm{LT}_{50}$ (Lethal temperature at which $50 \%$ of tillers died), LDur $_{50}$ (Lethal duration at which $50 \%$ of tillers died), tiller survival, and shoot biomass were examined with a factorial analysis of variance and orthogonal contrasts (Little and Hills 1978). Where significant differences existed, means were compared using LSD. The following orthogonal contrasts were conducted: 1 . Control vs. mowing; 2. May vs. June mowing; 3. July vs. August mowing, and; 4. May and June mowing vs. July and August mowing. Relationships between freezing temperature or duration of exposure to $-15^{\circ} \mathrm{C}$ and $\mathrm{LT}_{50}, \mathrm{LDur}_{50}$, tiller survival and shoot biomass in the 5 mowing treatments were characterized using regression analysis (Little and Hills 1978). Contrasts were conducted to determine whether regression relationships for each experiment were linear, quadratic, or cubic in relation to freezing duration or temperature. In all cases, percent survival data were transformed into their arcsine before analysis; untransformed data are presented to provide a clear expression of results.

Water content of tillers was analyzed with analysis of variance. Where significant differences existed, treatment means werc compared using LSD. Statistical significance was at $\mathbf{P}<0.05$ in all experiments.

\section{Results}

\section{Varying Degrees Of Cold Stress}

In all tests, tiller survival and biomass production decreased as temperatures declined from -3 to $-36^{\circ} \mathrm{C}$. In early and late winter 1992-93, $\mathrm{LT}_{50}$ of mowed tillers was about 3 to $6^{\circ} \mathrm{C}$ lower than that of the control (Table 1). In early winter 1992-93, tillers mowed in May or July had lower LT $_{50}$ than those mowed in August. $\mathrm{LT}_{50}$ was similar among mowing treatments in late winter, averaging $-22.0^{\circ} \mathrm{C}$. Among mowed tillers, early winter survival was greatest for those treated in July and poorest for those in the August treatment, but none of these differences persisted into late winter (Fig.1).

Table 1. The $\mathbf{L T}_{50}$ (temperature $\left({ }^{\circ} \mathrm{C}\right.$ ) at which $\mathbf{5 0 \%}$ of the tillers died) for northern wheatgrass tillers mowed in 1992 , collected in winter 1992-1993, and exposed to a temperature gradient of -3 to $-36^{\circ} \mathrm{C}$.

\begin{tabular}{lcc}
\hline Time of & \multicolumn{2}{c}{ Time of collection } \\
\cline { 2 - 3 } mowing & Early winter & Late winter \\
\hline & $-\ldots-18.1 \mathrm{~d}^{1}$ & $-18.1 \mathrm{~b}$ \\
Control & $<-36.0 \mathrm{ab}$ & $-22.5 \mathrm{a}$ \\
May & $-34.5 \mathrm{bc}$ & $-21.4 \mathrm{a}$ \\
Jun & $<-36.0 \mathrm{ab}$ & $-22.6 \mathrm{a}$ \\
Jul & $-32.7 \mathrm{c}$ & $-21.3 \mathrm{a}$ \\
Aug & 1.0 & 0.8 \\
SE & & 0.8
\end{tabular}

Means within columns followed by the same letter are not significantly different using LSD $(P>0.05)$

In early and late winter $1993-94$, LT $_{50}$ was similar among all treatments, averaging $-24.0(\mathrm{SE}=1.2)$ and $-22.0^{\circ} \mathrm{C}(\mathrm{SE}=1.9)$, respectively. In early winter 1993-94, survival of mowed tillers was greater than survival in control (Fig. 2). Orthogonal contrasts among mowing treatments, excluding control, revealed that in early and late winter 1993-94, tillers mowed in May or June had greater survival over the range of temperatures than those mowed in July or August (Fig. 2). 

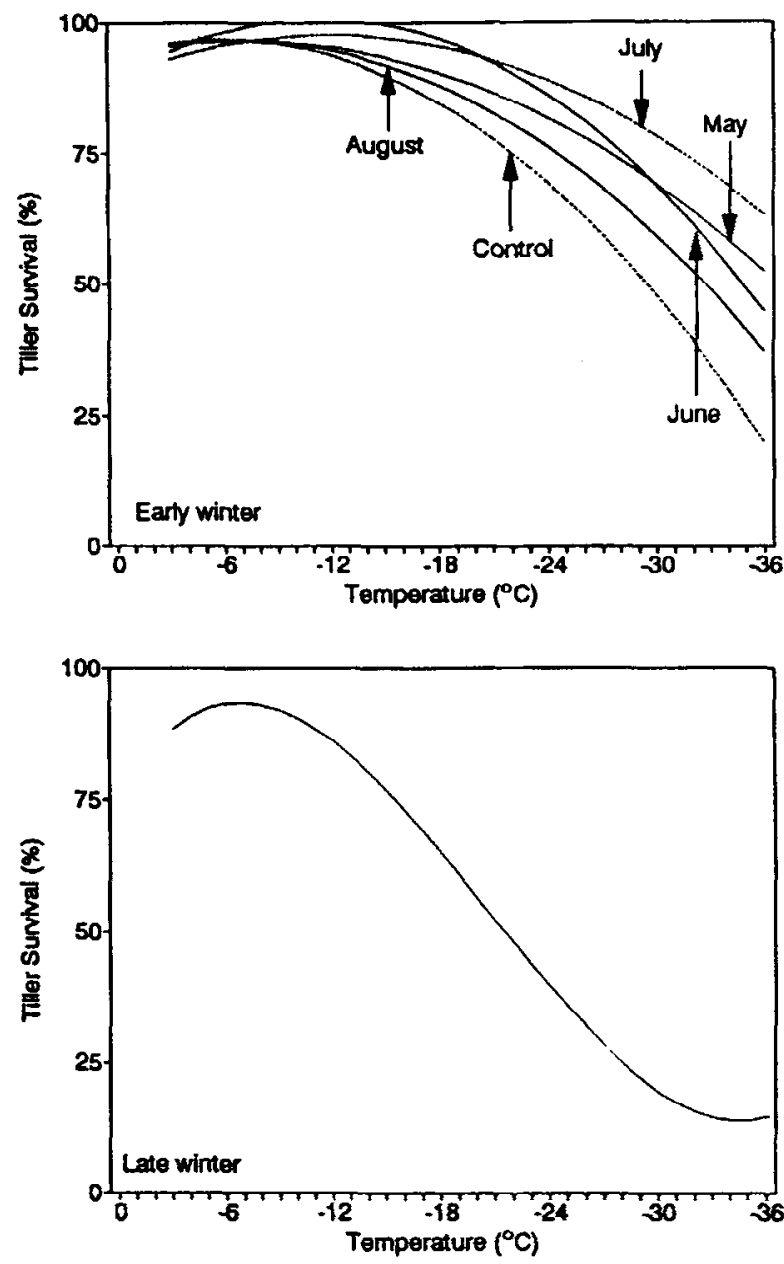

Fig. 1. Response curves for survival of northern wheatgrass tillers mowed in 1992 and exposed to temperatures between -3 and $-36^{\circ} \mathrm{C}$ in early and late winter 1992-93. The regression equations for early winter are: $Y=93.6-1.05 X-0.862 X^{2}, R^{2}=0.97$ for control; $Y=93.7-0.787 X-0.0538 X^{2}, R^{2}=0.86$ for $M a y ; Y=88.7-2.14 X-0.0936 X^{2}$, $R^{2}=0.92$ for June; $Y=89.2-1.42 X-0.0596 X^{2}, R^{2}=0.82$ for July, and; $Y=93.2-0.974 X-0.0704 X^{2}, R^{2}=0.90$ for August. The regression equation for late winter is: $Y=76.3-5.32 X-0.47 X 2-0.0076 X^{3}, R^{2}=0.98$.

Total tiller biomass was similar among mowing treatments in early and late winter 1992-93 (Fig. 3). In early winter 1993-94, contrasts indicated tillers mowed in May or June were heavier than those treated in July or August (Fig. 4); biomass of control tillers was between these extremes. In late winter 1993-94, tiller biomass was similar among all treatments (Fig. 4).

Table 2. The LDur 50 (duration (days) at which $50 \%$ of tillers died) and weights for northern wheatgrass tillers exposed to $-15^{\circ} \mathrm{C}$ for 0 to 15 days in late winter of 1993-94.

\begin{tabular}{|c|c|c|c|c|c|}
\hline \multirow[b]{2}{*}{ Control } & \multicolumn{4}{|c|}{ Time of mowing in 1993} & \multirow[b]{2}{*}{ SE } \\
\hline & May & Jun & Jul & Aug & \\
\hline $3.3 b c^{1}$ & $4.1 \mathrm{ab}$ & $2.7 \mathrm{c}$ & $\begin{array}{l}\text { (LDur } \\
4.7 a\end{array}$ & $4.1 \mathrm{ab}$ & \\
\hline $0.14 \mathrm{bc}$ & $0.15 \mathrm{abc}$ & $0.12 \mathrm{c}$ & $\begin{array}{r}0 \text { tiller } \\
0.17\end{array}$ & $0.16 a b$ & 0.003 \\
\hline
\end{tabular}

Means within a parameter followed by the same letter are not significantly different using LSD ( $P>0.05$ )
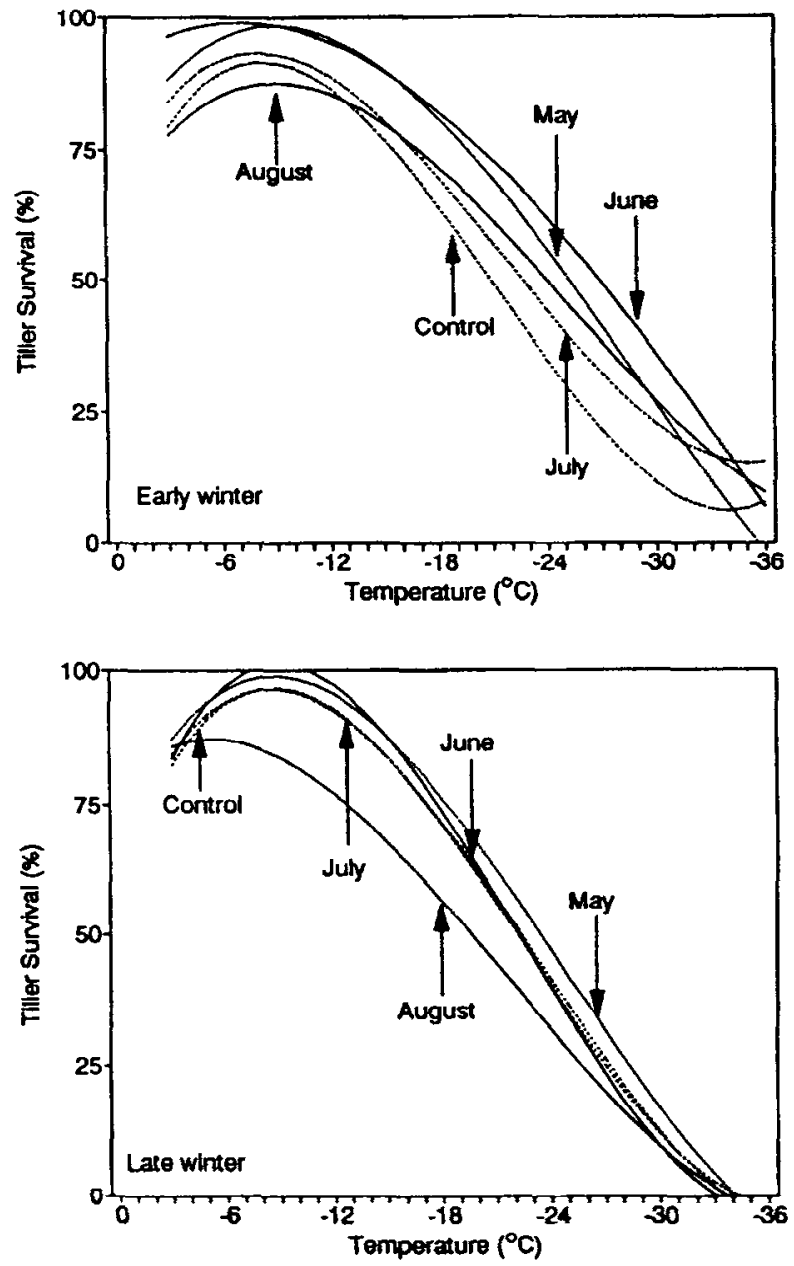

Fig. 2. Response curves for survival of northern wheatgrass tillers mowed in 1993 and exposed to temperatures between -3 and $-36^{\circ} \mathrm{C}$ in early and late winter 1993-94. The regression equations for early winter are: $Y=59.4-8.48 X-0.639 X^{2}-0.0101 X^{3}, R^{2}=0.98$ for control; $Y=74.4-5.67 X-0.374 X^{2}-0.00438 X^{3}, R^{2}=0.99$ for May; $Y=90.5-2.47 X-0.192 X^{2}-0.00163 X^{3}, \quad R^{2}=0.96$ for June; $Y=68.4-6.69 X-0.051 X^{2}-0.00787 X^{3}, R^{2}=0.91$ for $J u l y$, and $Y=64.1-5.65 X-0.383 X^{2}-0.00511 X^{3}, R^{2}=0.97$ for August. The regression equations for late winter are: $Y=65.6-7.82 X-0.561 X^{2}-0.00804 X^{3}$, $R^{2}=0.97$ for control; $Y=69.5-7.27 X-0.507 X^{2}-0.00687 X^{3}, R^{2}=0.95$ for May; $Y=58.4-10.4 X-0.725 X^{2}-0.0108 X^{3}, R^{2}=0.98$ for June; $Y=61.0-8.87 X-0.629 X^{2}-0.00929 X^{3}, R^{2}=0.95$ for July, and; $Y=79.3-3.1 X-0.336 X^{2}-0.00517 X^{3}, R^{2}=0.96$ for August.

\section{Varying Durations of Cold Stress}

In early winter, tiller survival decreased linearly as duration of exposure to $-15^{\circ} \mathrm{C}$ increased (Fig. 5). Survival of control tillers was lower than for mowed ones. Orthogonal contrasts indicated survival of tillers mowed in July was less than those treated in August. LDur $_{50}$ was similar among mowing treatments, averaging 10.1 days $(\mathrm{SE}=2.5$ ).

In late winter tiller survival decreased sharply and curvilinearly as duration of exposure to $-15^{\circ} \mathrm{C}$ increased (Fig. 5). Fewer control tillers survived than ones mowed in May, July, or August. May mowing resulted in higher survival than June mowing, and July mowing increased tiller survival compared to August. LDur $_{50}$ declined from early to late winter. In late winter, tillers from the May, July, or August mowing treatments tolerated 
Table 3. Weights for northern wheatgrass tillers exposed to $-15^{\circ} \mathrm{C}$ for 0 to 15 days averaged across the 5 mowing treatments imposed in 1993 .

\begin{tabular}{|c|c|c|c|c|c|c|c|c|c|c|c|c|}
\hline \multirow[b]{2}{*}{ Season } & \multicolumn{4}{|c|}{ Hours } & \multicolumn{8}{|c|}{ Days } \\
\hline & 0 & 2 & 12 & 24 & 2 & 3 & 4 & 5 & 6 & 7 & 15 & SE \\
\hline $\begin{array}{l}\text { Early } \\
\text { winter }\end{array}$ & $0.56 \mathrm{a}^{1}$ & $0.39 \mathrm{~b}$ & $0.57 \mathrm{a}$ & $0.54 \mathrm{a}$ & $0.53 a$ & $0.62 a$ & $0.39 \mathrm{bc}$ & $0.27 \mathrm{~d}$ & $0.30 \mathrm{bcd}$ & $0.36 \mathrm{bcd}$ & $0.08 \mathrm{e}$ & 0.056 \\
\hline $\begin{array}{l}\text { Late } \\
\text { winter }\end{array}$ & $0.35 \mathrm{a}$ & $0.22 \mathrm{~b}$ & $0.19 b c$ & $0.21 \mathrm{~b}$ & $0.21 \mathrm{~b}$ & $0.16 \mathrm{~cd}$ & $0.12 \mathrm{de}$ & $0.07 \mathrm{ef}$ & $0.04 \mathrm{fg}$ & $0.08 \mathrm{ef}$ & $0.01 \mathrm{~g}$ & 0.024 \\
\hline
\end{tabular}

${ }^{1}$ Means within rows followed by the same letter are not significantly different using $\operatorname{LSD}(\mathrm{P}>0.05)$.

$-15^{\circ} \mathrm{C}$ about $60 \%$ longer than June mowing (Table 2). LDur 50 was similar for the control and June mowing.

In early winter tiller weights were similar among mowing treat-

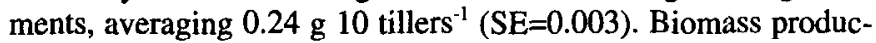
tion of tillers was, however, reduced by exposure to $-15^{\circ} \mathrm{C}$ for more than 3 days (Table 3 ). Weights of tillers held at $-15^{\circ} \mathrm{C}$ for 2 hours were inexplicably less than those exposed for 12 hours to 3 days. In late winter biomass of tillers was reduced by exposure to $-15^{\circ} \mathrm{C}$ for 2 hours or more, and progressively declined with increasing duration (Table 3). Averaged over the 0 to 15 day duration, control tillers and those mowed in June were smaller than ones treated in July (Table 2).

\section{Tiller Water Content}

In early winter 1993-94, water content of control and June mowed tillers was less than those nowed in May or July (Table 4). Water content of tillers mowed in August was intermediate to these extremes. Tillers mowed in May or June had the lowest water content in late winter, while that of control and August mowed tillers was greatest.

\section{Discussion}

Apart from late winter 1993-94, survival of control tillers was poorer than mowed tillers in all experiments, an unexpected response because most research suggests that defoliation reduces

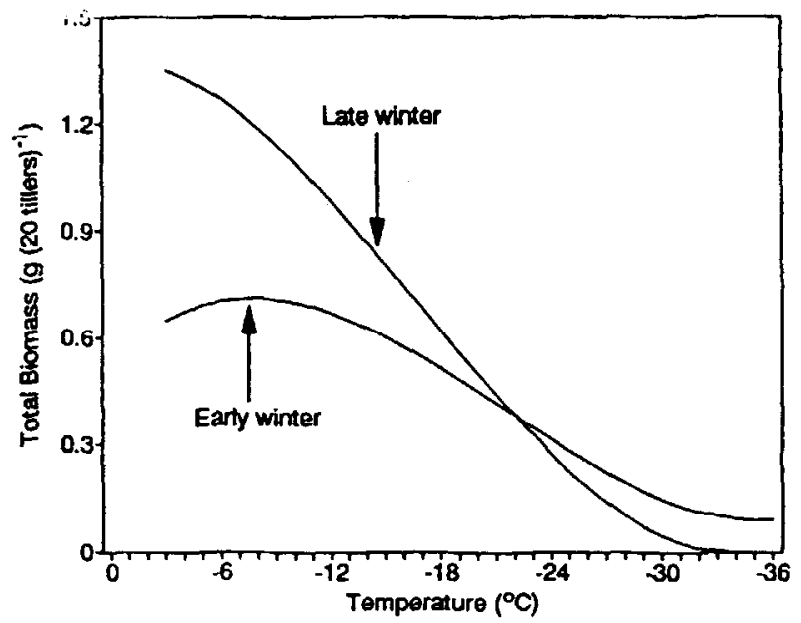

Fig. 3. Response curves for biomass production of northern wheatgrass tillers mowed in 1992 and exposed to temperatures hetween -3 and $-36^{\circ} \mathrm{C}$ in early and late winter $1992-93$. The regression equation for early winter is $Y=0.538-0.0485 X-0.00385 X^{2}-0.000060 X^{3}$, $R^{2}=0.98$, and late winter $Y=1.38-0.0017 X-0.00379 X^{2}-0.000075 X^{3}$, $\mathbf{R}^{2}=0.98$. winter survival of plants (Biswell and Weaver 1933, Lawrence and Ashford 1969a, 1969b). We therefore reject the hypothesis that a single defoliation reduces cold-hardiness of northern wheatgrass.

Several factors likely contributed to the observed differences in tiller survival. Plants were ungrazed for $>25$ years before mowing and likely possessed maximum vigor. Single mowing of plants in this study likely produced fewer negative effects on physiology and tiller survival than repeated defoliation. Better survival of mowed tillers may have been caused by defoliationdependent mortality. Mowing may have killed weaker tillers, leaving only the hardiest. Temperature and water availability can also affect the hardening and dehardening processes in plants.

Findings from 1992-93 suggest that control tillers contained more water than mowed ones. In early winter 1993-94, however, water content of control tillers was low, and their survival was poorest. Reduced water content in crowns or tillers typically increases cold-hardiness (Gusta and Chen 1987). Excluding control, water content of tillers was correlated with survival; drier tillers survived better than those containing more water. An exception to this occurred when tillers were exposed to $-15^{\circ} \mathrm{C}$ for 0 to 15 days; water content of tillers did not correlate with the relatively poor survival of tillers mowed in June or higher survival of those mowed in August. Since tiller water content did not explain all differences in survival, other factors must be involved.

Cold-hardiness may be induced by abscisic acid (Reaney and Gusta 1987, Salisbury and Ross 1992) which in turn induces bud dormancy in plants. Production of abscisic acid is stimulated by water stress, which as indicated, may have been greater in defoliated plants. Water stress may have also reduced cell size (Salisbury and Ross 1992), and tissues with smaller cells are less prone to freezing injury than those with larger ones (Levitt 1980).

Reduced cover on mowed plots may have predisposed plants to ambient air temperatures (Whitman 1974). As temperatures cooled in autumn and hardening began, colder temperatures may have enabled mowed plants to harden more rapidly and thoroughly than in control. On the other hand colder temperatures that

Table 4. Crown water content of northern wheatgrass tillers mowed in 1993 and collected the following winter.

\begin{tabular}{|c|c|c|}
\hline \multirow{2}{*}{$\begin{array}{l}\text { Time of } \\
\text { mowing }\end{array}$} & \multicolumn{2}{|c|}{ Time of collection } \\
\hline & Early winter & Late winter \\
\hline \multicolumn{3}{|c|}{$\ldots \ldots$ (\% of dry weight $) \ldots \ldots$} \\
\hline Control & $182 b^{1}$ & $279 \mathrm{ab}$ \\
\hline May & $202 \mathrm{a}$ & $244 c$ \\
\hline Jun & $180 b$ & $260 c$ \\
\hline Jul & $205 a$ & $264 b c$ \\
\hline Aug & $196 a b$ & $288 \mathrm{a}$ \\
\hline SE & 8 & 8 \\
\hline
\end{tabular}

Means within a column followed by the same letter are not significantly different (P> 0.05) using LSD. 

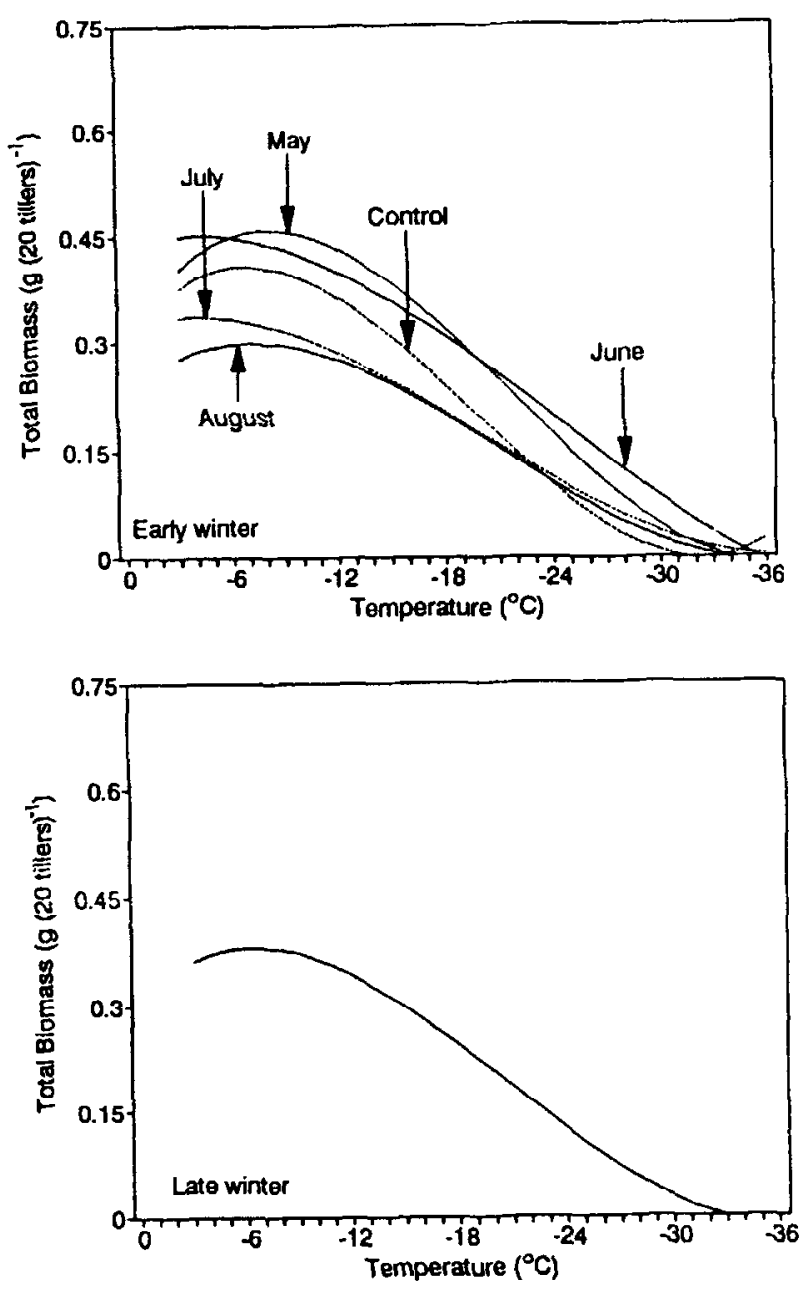

Fig. 4. Response curves for biomass production of northern wheatgrass tillers mowed in 1993 and exposed to temperatures between -3 and $-36^{\circ} \mathrm{C}$ in early and late winter $1993-94$. The regression equations for early winter are: $Y=0.306-0.0324 X-0.00288 X^{2}-0.000049 X^{3}$, $R^{2}=0.98$ for control; $Y=0.313-0.0388 X-0.00294 X^{2}-0.000045 X^{3}$, $R^{2}=0.98$ for May; $Y=0.434-0.0088 X-0.00116 X^{2}-0.000016 X^{3}, R^{2}=0.97$ for June; $Y=0.319-0.0089 X-0.00121 X^{2}-0.00002 X^{3}, R^{2}=0.92$ for July, and; $Y=0.231-0.0205 X-0.0017 X^{2}-0.000027 X^{3}, R^{2}=0.96$ for August. The regression equation for late winter is $Y=0.312-$ $0.0226 X-0.00206 X^{2}-0.000033 X^{3}, R^{2}=0.98$.

mowed plants experience may also reduce tiller survival. Plants typically begin dehardening in late winter and early spring when soil temperatures increase (McKenzie and McLean 1980). Since temperatures to which mowed plants are exposed are more closely linked to prevailing air temperatures, plants may deharden sooner and more rapidly, and suffer greater freezing-related damage (Ouellet 1977). Thus, although mowed tillers tolerated low temperatures better than the control, they also experienced more cold stress in the field (Kowalenko 1995) because of reduced cover, less insulation, and less snow-trapping.

In early winter 1992-93 tillers were more cold-hardy than in 1993-94. Tillers were collected about 2 weeks later in 1992 than in 1993. In 1993, tillers may not have achieved their maximum level of cold-hardiness, while in 1992 plants were probably fully hardened (Gusta and Chen 1987). Environmental conditions that favor growth in autumn can reduce cold-hardening of plants
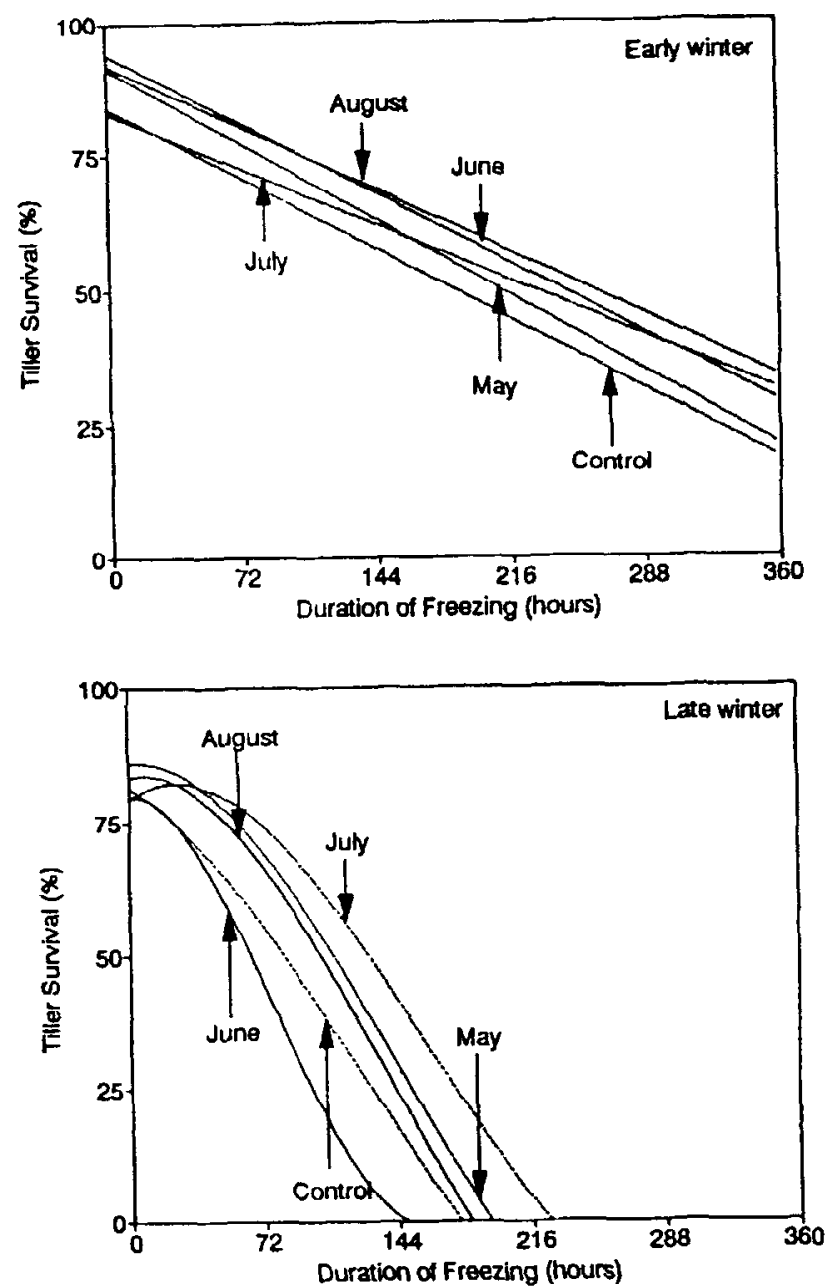

Fig. 5. Response curves for survival of northern wheatgrass tillers mowed in 1993 and exposed to $-15^{\circ} \mathrm{C}$ for 0 to 15 days in early and late winter 1993-94. Regression equations for early winter are $Y=84.3-0.18 X, r^{2}=0.79$ for control; 91.8-0.196X, $r^{2}=0.93$ for May; $Y=94.5-0.18 X, r^{2}=0.90$ for June; $Y=83.2-0.144 X, r^{2}=0.87$ for July, and; $Y=92.4-0.162 X, r^{2}=0.90$ for August. Regression equations for late winter are: $Y=81.3-0.198 X-0.00272 X^{2}-0.00272 x^{3}, R^{2}=0.94$ for control; $Y=85.7+0.043 X-0.00445 X^{2}+0.00001 X^{3}, R^{2}=0.95$ for May; $Y=79.6+0.038 X-0.0104 X^{2}+0.000044 X^{3}, R^{2}=0.95$ for June; $Y=79.2+0.229 X-0.00483 X^{2}+0.00001 X^{3}, R^{2}=0.91$ for July, and; $Y=83.2+0.077 X-0.00511 X^{2}+0.000012 X^{3}, R^{2}=0.93$ for August.

(McKenzie and McLean 1980). In the present study, moist soil in autumn 1993 may have stimulated growth and delayed hardening. By comparison minimal growth occurred in 1992 when moisture was limited.

In summary, northern wheatgrass potentially may become very cold-hardy; $\mathrm{LT}_{50}$ ranging from -29.5 to $<-36.0^{\circ} \mathrm{C}$ place this species among the most cold-hardy grasses of the Canadian Prairies. Other native grasses from this region tolerated temperatures of -27 to $-35^{\circ} \mathrm{C}$ (Limin and Fowler 1987, Schwarz and Reaney 1989). Although the likelihood of damage to northern wheatgrass from freezing is usually low (Kowalenko 1995) some tillers will die each winter because of exposure to lethal, freezing temperatures. Reductions in tiller survival and biomass production begin when temperatures fall between -12 and $-18^{\circ} \mathrm{C}$, and damage to plants from freezing is most likely when they dehard- 
en in late winter through early spring. It is therefore critical to maintain a protective cover of dead phytomass during this period for standing plant material can moderate soil temperatures by $4-5^{\circ} \mathrm{C}$ (Aase and Siddoway 1979), reducing cold-stress on plants (Kowalenko 1995). Presence of dead phytomass also enhances productivity on Northern Mixed Prairie (Willms et al. 1986, 1993). Under proper management (Zhang and Romo 1994, Kowalenko and Romo 1997) winter survival and productivity of northern wheatgrass should not be impaired.

\section{Literature Cited}

Aase, J.K. and F.H. Siddoway. 1979. Crown depth soil temperatures and winter protection for winter wheat survival. Soil Sci. Soc. Amer. J. 43:1229-1233.

Biswell, H.H. and J.E. Weaver. 1933. Effect of frequent clipping on the development of roots and tops of grasses in prairie sod. Ecol. 14:368-390.

Burke, M.J., L.V. Gusta, H.A. Quamme, C.J, Weiser, and P.H. Li. 1976. Freezing and injury in plants. Annu. Rev. Plant Physiol. 27:507-528.

Coupland, R.T. 1950. Ecology of mixed prairie in Canada. Ecol. Monogr. 20:271-315.

Coupland, R.T., J.R. Willard, and E.A. Ripley. 1974. Summary of activities, 1967-1974. Matador Proj. Tech. Rep. No. 69. Univ. Sask., Saskatoon, Sask.

Environment Canada, Atmospheric Environment Service. 1992. Canadian climate normals (1961-1990), temperature and precipitation (Prairie provinces). Environment Canada, Ottawa, Ontario.

Gusta, L.V. and T.H.H. Chen. 1987. The physiology of water and temperature stress, p. 115-150. In: Wheat and wheat improvement Agron. Monogr. No. 13 (2nd ed.) Madison, Wis.

Harrison, T. and J.T. Romo. 1994. Regrowth of smooth bromegrass (Bromus inermis Leyss.) following defoliation. Can. J. Plant Sci. 74:531-537.

Johnston, A., J.F. Dormaar, and S. Smoliak. 1971. Long-term grazing effects on fescue grassland soils. J. Range Manage. 24:185-188.

Kowalenko, B.L. 1995. Rest requirements and cold hardiness of northern wheatgrass (Agropyron dasytachyum (Hook.) Scribn.) following defoliation. M.Sc. Thesis, Univ. Saskatchewan, Saskatoon, Sask.

Kowalenko, B.L. and J.T. Romo. 1997. Rest requirements of northern wheatgrass following defoliation. J. Range Manage. 51:73-78.

Lawrence, T. and R. Ashford. 1969a. Effect of nitrogen fertilizer and clipping frequency on the dry matter yield and persistency of intermediate whcatgrass. Can. J. Plant Sci. 49:435-446.

Lawrence, T. and R. Ashford. 1969b. Effect of stage and height of cutting on the dry matter yield, and persistence of intermediate wheatgrass, bromegrass and reed canarygrass. Can. J. Plant Sci. 49:321-332.

Levitt, J. 1980. Responses of plants to environmental stresses. Vol. 1. Chilling, freezing, and high temperature stresses. Academic Press, Toronto, Ontario.

Limin, A.E. and D.B. Fowler. 1987. Cold hardiness of forage grasses grown on the Canadian prairies. Can. J. Plant Sci. 67:1111-1115.

Little, T.M. and F.J. Hills. 1978. Agricultural experimentation-Design and analysis. John Wiley and Sons, Toronto, Ontario.

McKenzie, J.S. and G.E. McLean. 1980. Changes in the cold hardiness of alfalfa during five consecutive winters at Beaverlodge, Alberta. Can. J. Plant Sci. 60:703-712.

Ouellet, C.E. 1977. Monthly climatic contribution to the winter injury of alfalfa. Can. J. Plant Sci. 57:419-426.

Reaney, M.J.T. and L.V. Gusta. 1987. Factors influencing the induction of freezing tolerance by abscisic acid in cell suspension cultures of Bromus inermis Leyss. and Medicago sativa L. Plant Physiol. 83:423-427.

Salisbury, F.B. and C.W. Ross. 1992. Plant Physiol., 4th ed. Wadsworth Pub. Co., Belmont, Calif.
Schwarz, A.G. and M.J.T. Reaney. 1989. Perennating structures and freezing tolerance of northern and southern populations of $\mathrm{C}_{4}$ grasses. Bot. Gaz. 150:239-246.

Whitman, W.C. 1974. Influence of grazing on the microclimate of mixed grass prairie, p. 207-218. In: K.W. Krietlow and R.H. Hart (coordinators). Plant morphogenesis as the basis for scientific management of range resources. USDA Misc. Pub. 1271.

Willms, W.D., S. Smoliak, and A.W. Bailey. 1986. Herbage production following litter removal on Alberta native grasslands. J. Range Manage. 39:536-540.

Willms, W.D., S.M. McGinn, and J.F. Dormaar. 1993. Influence of litter on herbage production in the mixed prairie. J. Range Manage. 46:320-324.

Zhang, J, and J.T. Romo. 1994. Defoliation of a northern wheatgrass community: Above- and below-ground phytomass productivity. J. Range Manage. 47:279-284. 